\title{
Role of the stromal cell derived factor-1 in the biological functions of endothelial progenitor cells and its underlying mechanisms
}

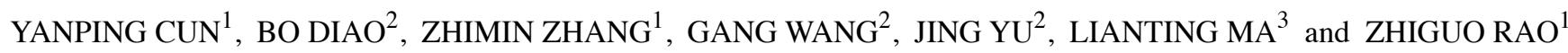 \\ Departments of ${ }^{1}$ Oncology, ${ }^{2}$ Clinical Experiment and ${ }^{3}$ Neurosurgery, \\ General Hospital of Central Theater Command, Wuhan, Hubei 430070, P.R. China
}

Received January 17, 2020; Accepted May 13, 2020

DOI: $10.3892 /$ etm.2020.9471

\begin{abstract}
Stromal cell derived factor-1 (SDF-1) is a chemokine that plays a critical role in the homing of stem and progenitor cells, including endothelial progenitor cells (EPCs). However, little research has been undertaken to evaluate the roles of SDF-1 in the biological functions of EPCs and related signaling pathways. The present study aimed to investigate the biological functions of EPCs in response to SDF-1, as well as the underlying mechanisms. The effects of SDF-1 treatment on EPC proliferation, migration and tube formation were assessed by performing MTS, Transwell and in vitro tube formation assays, respectively. The phosphorylation status of Akt and ERK was evaluated by western blotting. The present results indicated that SDF-1 treatment enhanced EPC proliferation, migration and tube formation compared with the control group. Furthermore, SDF-1-induced EPC proliferation was significantly reduced following treatment with a C-X-C Motif Chemokine Receptor 4 antagonist (AMD3100), a PI3K inhibitor (LY294002) and the mitogen-activated protein kinase kinase inhibitor (MEK; PD98059). SDF-1-induced migration and angiogenesis were significantly suppressed by the PI3K inhibitor, but not the MEK inhibitor. Moreover, SDF-1 significantly increased the protein expression levels of phosphorylated (p)-Akt and p-ERK; however, SDF-1-induced effects on protein expression were suppressed by AMD3100, LY294002 and PD98059. Thus, SDF-1-induced EPC proliferation was mediated by
\end{abstract}

Correspondence to: Professor Lianting Ma, Department of Neurosurgery, General Hospital of Central Theater Command, 627 Wuluo Road, Wuhan, Hubei 430070, P.R. China

E-mail: mlt1937@163.com

Professor Zhiguo Rao, Department of Oncology, General Hospital of Central Theater Command, 627 Wuluo Road, Wuhan, Hubei 430070 , P.R. China

E-mail: raozhiguo@hotmail.com

Key words: endothelial progenitor cells, stromal cell derived factor-1, biological functions, Akt signaling pathway, ERK signaling pathway activation of the Akt and ERK signaling pathways, whereas SDF-1-mediated EPC migration and tube formation only involved activation of the Akt signaling pathway.

\section{Introduction}

Since the discovery of endothelial progenitor cells (EPCs) by Asahara et al in 1997 (1), it has been reported that EPCs are involved in vascular repair and postnatal angiogenesis (2). Following stimulation with various factors such as velvet antler, hydrogen sulfide and danhong, EPCs migrate to sites of injury to promote angiogenesis and repair vascular endothelial cell damage (3-5). The mechanism underlying EPC-mediated repair of injured endothelium is not only associated with differentiation and transdifferentiation into EPCs, but also with the biological functions of EPCs, including proliferation, migration and tube formation (6,7). EPCs can also prevent neointima formation and participate in re-endothelialization in damaged vascular tissue (8). Moreover, previous studies have revealed that EPCs can produce new blood vessels during tumor growth, development and metastasis (9-11). Cerebrovascular disease (12), cardiovascular disease (13), chronic kidney disease (14) and cancer (15) development are associated with EPC dysfunction. Therefore, investigating the biological features of EPCs and the underlying mechanisms will be useful for identifying the therapeutic potential of EPCs for the repair of damaged vascular endothelium, and also for the synthesis of effective anti-angiogenic drugs to prevent EPC-mediated vasculogenesis during tumor growth and progression.

Stromal cell derived factor-1 (SDF-1), a member of the CXC chemokine family, is constitutively expressed on stromal cells in various tissues (16) and can regulate multiple physiological processes such as organogenesis, regeneration and tumorigenesis (17). SDF-1 is a small chemotactic signaling protein that promotes downstream effects primarily via the $\mathrm{C}-\mathrm{X}-\mathrm{C}$ Motif Chemokine Receptor (CXCR)4, a specific G protein-coupled receptor (18). Previous studies have reported that SDF-1 is a strong chemoattractant for $\mathrm{CD} 34^{+}$cells, including hematopoietic stem cells and EPCs, which highly express CXCR4 $(19,20)$. In addition, SDF-1 overexpression in the peripheral circulation induces mobilization of hematopoietic progenitors and stem cells, including EPCs (21). The increased expression of SDF-1 in ischemic muscles acts as a chemoattractant to support the 
homing of CXCR4 ${ }^{+}$EPCs (22). A previous study also revealed that locally administered SDF-1 promoted EPCs accumulation at the site of ischemia, which was associated with ischemic neovascularization (23). Furthermore, it has been reported that the SDF-1/CXCR4 axis in EPCs serves an important role during bone fracture healing (24).

A review has shown that SDF-1 binding to CXCR4 initiates several signaling pathways, which can result in a variety of responses that are important during the process of angiogenesis, such as chemotaxis, cell proliferation, migration and the secretion of angiopoietic factors (25). The PI3K/Akt and mitogen-activated protein kinase (MAPK)/ERK signal transduction pathways, which are mediated by SDF-1, contribute to cell migration, proliferation, tube formation, apoptosis and chemotaxis (26,27). For example, SDF-1-induced Akt and ERK activation results in lung cancer cell invasion and metastasis (28), sacral chondrosarcoma and glioblastoma cell cycle progression and epithelial-mesenchymal transition $(29,30)$, as well as ovarian cancer cell proliferation (31), and pre-B (26), F5M2 osteosarcoma (32) and epitheloid carcinoma (33) cell migration. It has been reported that SDF-1 serves a critical role in the regulation of EPC cellular functions, including cell proliferation and migration $(23,34)$. Zheng et al revealed that the PI3K/Akt signaling pathway, but not the MAPK/ERK signaling pathway, was required for SDF-1-mediated regulation of EPC migration (35). However, to the best of our knowledge, the effects of SDF-1 on EPC proliferation and tube formation, as well as the underlying mechanisms, have not been fully elucidated. Therefore, the present study aimed to investigate the effects of SDF-1 on EPC biological properties and to identify the possible underlying mechanisms.

\section{Materials and methods}

Ethics and animals. A total of 42 male Sprague-Dawley rats (weight, 150-180 g; age, 5-6 weeks) were provided by The Experimental Animal Center of General Hospital of Central Theater Command. All rats were housed in a temperature-controlled room $\left(22^{\circ} \mathrm{C}\right)$ with $50 \%$ humidity and maintained on a 12-h light/12-h dark cycle with food and water available ad libitum. The animal use and all experimental protocols were conducted in accordance with the National Institutes of Health Guide for Care and Use of Laboratory Animals (36) and were approved by the Animal Research Committee of The General Hospital of Central Theater Command (Wuhan, China).

EPC isolation and culture. Sprague Dawley rats were anesthetized with ether $(50 \mathrm{mg} / \mathrm{kg})$ and rapidly decapitated after the rats were fully anesthetized, which was determined with no response to a paw pinch and disappearance of righting and eyelid reflex. Then, the tibias and femurs were dissected and cleaned. The bone marrow was slowly flushed out from tibias and femurs using a syringe filled with PBS and the mononuclear cells were isolated using the density gradient centrifugation method (Lymphoprep 1.077; Axis-Shield Diagnostics Ltd.) at $1,600 \mathrm{x}$ for $15 \mathrm{~min}$ at $4^{\circ} \mathrm{C}$. After three washes with PBS, mononuclear cells were resuspended in fresh EGM-2 media (Lonza Group, Ltd.) supplemented with
$5 \%$ FBS (Hyclone; Cytiva), seeded on fibronectin-coated cell culture plates $\left(2 \times 10^{5}\right.$ cells $\left./ \mathrm{cm}^{2}\right)$ and incubated at $37^{\circ} \mathrm{C}$ with $5 \%$ $\mathrm{CO}_{2}$. Following incubation for $24 \mathrm{~h}$ at $37^{\circ} \mathrm{C}$, the medium was changed, non-adherent cells were removed and fresh EGM-2 media was replaced every 3 days before cells were used for subsequent experiments. Alterations in cell morphology were observed using an IX81 inverted phase-contrast microscope (Olympus Corporation; magnification, x200).

EPC characterization. The cellular morphologies at days 7 and 14 were used to identify the EPCs. To assess the endothelial phenotype of EPCs, Dil-labelled acetylated low-density lipoprotein (Dil-ac-LDL; Invitrogen; Thermo Fisher Scientific, Inc.) uptake was evaluated. Following culture for 7 days, cells were harvested and washed with PBS and incubated with Dil-ac-LDL $(10 \mu \mathrm{g} / \mathrm{ml})$ for $4 \mathrm{~h}$ at $37^{\circ} \mathrm{C}$ with $5 \% \mathrm{CO}_{2}$. Following fixation with $4 \%$ phosphate-buffered paraformaldehyde for $10 \mathrm{~min}$ at room temperature, cells were stained with FITC-labeled Ulex europaeus agglutinin-1 (UEA-1; Sigma-Aldrich; Merck KGaA) for $1 \mathrm{~h}$ at $37^{\circ} \mathrm{C}$ with $5 \% \mathrm{CO}_{2}$. Subsequently, cells were washed with PBS and stained for 15 min with Hoechst at room temperature. Triple-positive cells (Dil-ac-LDL, FITC-UEA-1 and Hoechst) were identified as EPCs. Stained cells were observed using a fluorescence microscope (Olympus Corporation; magnification, x200).

Surface antigen expression was assessed by flow cytometry using a FC500 flow cytometer (Beckman Coulter, Inc.). Following culture for 7 days, cells were harvested and washed in PBS, and then resuspended in flow cytometry wash buffer ( $2 \%$ FBS; Hyclone; Cytiva) and $0.1 \%$ sodium azide in PBS). The cells were blocked in $10 \%$ (v/v) normal goat serum (Abcam) for $15 \mathrm{~min}$ at $4^{\circ} \mathrm{C}$. Subsequently, cells $\left(1 \times 10^{6}\right)$ were suspended in PBS, and then incubated with monoclonal antibodies: FITC-conjugated anti-CD133 antibody (cat. no. orb467002; Biorbyt Ltd.; 1:300), FITC-conjugated anti-CD34 antibody (cat. no. sc-7324; Santa Cruz Biotechnology, Inc.; 1:300) and FITC-conjugated anti-vascular endothelial growth factor receptor 2 antibody (VEGFR-2; cat. no. ab184903; Abcam; 1:300) for $30 \mathrm{~min}$ at $4^{\circ} \mathrm{C}$. The stained samples were analyzed using the flow cytometer.

Cell proliferation assay. To investigate whether SDF-1 treatment regulated EPC proliferation, cells $\left(1 \times 10^{5}\right.$ cells/well $)$ were treated with different concentrations of SDF-1 $(10,100$ and $500 \mathrm{ng} / \mathrm{ml}$; Abcam) in 6-well plates for $24 \mathrm{~h}$ at $37^{\circ} \mathrm{C}$ with $5 \%$ $\mathrm{CO}_{2}$. Then, EPCs were harvested and seeded $\left(1 \times 10^{4}\right.$ cells/well $)$ into 96-well culture plates and incubated with SDF-1 (10, 100 and $500 \mathrm{ng} / \mathrm{ml}$ ) again for another $48 \mathrm{~h}$.

To investigate the mechanisms underlying SDF-1-mediated

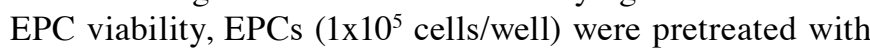
CXCR4 antagonist AMD3100 (60 $\mu \mathrm{M}$; Sigma-Aldrich; Merck KGaA), PI3K inhibitor LY294002 (20 $\mu \mathrm{M}$; Selleck Chemicals) or MEK inhibitor PD98059 (20 $\mu \mathrm{M}$; Sigma-Aldrich; Merck $\mathrm{KGaA}$ ) for $2 \mathrm{~h}$ at $37^{\circ} \mathrm{C}$, and then stimulated with SDF-1 $(100 \mathrm{ng} / \mathrm{ml})$ for $24 \mathrm{~h}$ in 6 -well plates at $37^{\circ} \mathrm{C}$ with $5 \% \mathrm{CO}_{2}$. EPCs were harvested and seeded $\left(1 \times 10^{4}\right.$ cells/well) into 96-well culture plates and incubated with SDF-1 (100 ng/ml) again for $48 \mathrm{~h}$.

Cell proliferation was measured using the colorimetric MTS assay (Cell Titer 96 Aqueous; Promega Corporation), 
according to the manufacturer's protocol. MTS reagent $(20 \mu \mathrm{l})$ was added to each well and incubated for $1 \mathrm{~h}$ at $37^{\circ} \mathrm{C}$. The optical density (OD) value of each well was measured at a wavelength of $490 \mathrm{~nm}$ using a 96-well plate reader (Bio-Rad Laboratories, Inc.).

Cell migration assay. Cell migration assays were performed using the $8-\mu \mathrm{m}$ pore 24 -well Cell Migration assay kit (BD Biosciences). Cells were pretreated with AMD3100 (60 $\mu \mathrm{M})$, LY294002 $(20 \mu \mathrm{M})$, PD98059 $(20 \mu \mathrm{M})$ or control EGM-2 medium for $2 \mathrm{~h}$ at $37^{\circ} \mathrm{C}$ with $5 \% \mathrm{CO}_{2}$. Subsequently, cells were incubated in plates with SDF-1 $(100 \mathrm{ng} / \mathrm{ml})$ or control EGM-2 medium for $24 \mathrm{~h}$ at $37^{\circ} \mathrm{C}$ ( $\mathrm{n}=6$ wells/group). Cells $\left(1 \times 10^{5}\right.$ cells/well) were serum-starved for $24 \mathrm{~h}$ at $37^{\circ} \mathrm{C}$ with $5 \% \mathrm{CO}_{2}$ and seeded into the upper chamber with serum-free culture medium. EGM-2 medium supplemented with 5\% FBS containing SDF-1 (100 ng/ml) or control EGM-2 medium was added into the lower chambers. Following incubation at $37^{\circ} \mathrm{C}$ for $24 \mathrm{~h}$ with $5 \% \mathrm{CO}_{2}$, cells on the upper surface were removed using cotton-tipped swabs. Cells on the lower surface of the membrane were fixed using $95 \%$ dehydrated alcohol for $30 \mathrm{~min}$ at room temperature and stained with crystal violet for $15 \mathrm{~min}$ at room temperature. After washing three times with PBS, stained cells were observed in five random fields of view using an IX81 inverted phase-contrast microscope (Olympus Corporation; magnification, x100).

Tube formation assay. The tube formation assay was performed using Matrigel ${ }^{\circledR}$ (BD Biosciences), according to the manufacturer's instructions. Matrigel ${ }^{\circledR}$ was thawed overnight at $4^{\circ} \mathrm{C}$. The 96 -well plate and $100 \mu$ l pipette tips were also maintained at $4^{\circ} \mathrm{C}$ overnight. Subsequently, Matrigel $^{\circledR}(30 \mu \mathrm{l} /$ well) was added to the 96 -well plate and incubated at $37^{\circ} \mathrm{C}$ for $1 \mathrm{~h}$. To investigate the effect of SDF-1 on tube formation of EPCs and the underlying mechanism, AMD3100 $(60 \mu \mathrm{M})$, LY294002 $(20 \mu \mathrm{M})$ or PD98059 $(20 \mu \mathrm{M})$ was added to culture medium for $2 \mathrm{~h}$ at $37^{\circ} \mathrm{C}$ with $5 \% \mathrm{CO}_{2}$. Then, cells were incubated with SDF-1 (100 ng/ml) for $24 \mathrm{~h}$ at $37^{\circ} \mathrm{C} 5 \% \mathrm{CO}_{2}$. EPCs $\left(1 \times 10^{4}\right.$ cells/well $)$ were added to the surface of the Matrigel ${ }^{\circledR}$ in the 96 -well plate and incubated at $37^{\circ} \mathrm{C}$ for $4 \mathrm{~h}$. Tube formation was observed using an IX81 inverted phase-contrast microscope (Olympus Corporation; magnification, $x 100)$. Images were acquired at the same magnification. The total branching length of the vascular network was determined using ImageJ software version 1.51 (National Institutes of Health).

Western blotting. EPCs $\left(1 \times 10^{5}\right.$ cells/well) were cultured in 6 -well plates and at 80\% confluence pretreated with AMD3100 $(60 \mu \mathrm{M})$, LY294002 $(20 \mu \mathrm{M})$ or PD98059 $(20 \mu \mathrm{M})$ for $2 \mathrm{~h}$ at $37^{\circ} \mathrm{C}$ with $5 \% \mathrm{CO}_{2}$. Subsequently, EPCs were stimulated with $100 \mathrm{ng} / \mathrm{ml} \mathrm{SDF}-1$ for $1 \mathrm{~h}$ at $37^{\circ} \mathrm{C}$ with $5 \% \mathrm{CO}_{2}$. The concentrations of inhibitor used in the present study were based on previous studies $(17,25,26)$. Total protein was extracted using RIPA lysis buffer (Santa Cruz Biotechnology, Inc.) with phosphatase inhibitor and phenylmethanesulfonyl fluoride. Total protein was quantified using the Bradford method (37). The whole cell extracts $(30 \mu \mathrm{g})$ were separated via $10 \%$ SDS-PAGE and transferred onto PVDF membranes (Bio-Rad Laboratories, Inc.), which were blocked with 5\% non-fat milk for $1 \mathrm{~h}$ at $37^{\circ} \mathrm{C}$. Subsequently, the membranes were incubated at $4^{\circ} \mathrm{C}$ overnight with the following primary antibodies: Anti-Akt (cat. no. 2920S; Cell Signaling Technology, Inc.; 1:2,000), anti-phosphorylated (p)-Akt (cat. no. 4051S; Cell Signaling Technology, Inc.; 1;2,000), anti-ERK (cat. no. 4696S; Cell Signaling Technology,Inc.; 1:1,000), anti-p-ERK(cat.no.9106S; Cell Signaling Technology, Inc.; 1:1,000) and anti- $\beta$-actin (cat. no. 3700S; Cell Signaling Technology, Inc.; 1:1,000). Following primary incubation, the membranes were washed with TBST [TBS with $0.1 \%$ (v/v) Tween-20] and incubated with corresponding horseradish peroxidase-conjugated goat anti-rat immunoglobulin $\mathrm{G}$ secondary antibody (cat. no. 7077S; Santa Cruz Biotechnology, Inc.; 1:3,000) for $1 \mathrm{~h}$ at $37^{\circ} \mathrm{C}$. The membranes were washed with TBST and protein bands were visualized using chemiluminescent solution (EMD Millipore). Protein expression levels were quantified using Quantity One software (version 4.4; Bio-Rad Laboratories, Inc.).

Statistical analysis. Data are presented as the mean \pm standard deviation of $\geq 3$ individual experiments. In cell experiments, six replicate wells were performed for each group. Statistical analyses were performed using SPSS software (version 18.0; SPSS, Inc.). Differences among groups were analyzed using one-way ANOVA followed by Bonferroni's post hoc test. $\mathrm{P}<0.05$ was considered to indicate a statistically significant difference.

\section{Results}

EPC characterization. Cells displayed spindle-like morphology at day 7 and cobblestone-like morphology at day 14 (Fig. 1A). Following cell culture for 7 days in EGM-2 media, the tube formation ability of the attached cells was determined using the Matrigel ${ }^{\circledR}$ network formation assay (Fig. 1B). Following culture for 7 days in EGM-2 media, cells were harvested and assessed by flow cytometry. FACS analysis indicated that the adherent cells expressed progenitor or stem cell markers CD133 and CD34, and the endothelial cell marker VEGFR2 (Fig. 1C). EPCs were further characterized by performing a Dil-ac-LDL uptake and FITC-UEA-1 binding assay after 7 days of culture in EGM-2 media (Fig. 1D), and it was identified that the cultured cells were EPCs.

Effect of SDF-1 on EPC proliferation and the underlying mechanism. The effects of SDF-1 on EPC proliferation were investigated. The maximum increase in EPC proliferation was observed in the $100 \mathrm{ng} / \mathrm{ml} \mathrm{SDF}-1$ treatment group, and no further increase in EPC proliferation was observed in the $500 \mathrm{ng} / \mathrm{ml} \mathrm{SDF}-1$ treatment group. SDF-1 (100 and $500 \mathrm{ng} / \mathrm{ml}$ ) significantly enhanced EPC proliferation compared with the control, and $100 \mathrm{ng} / \mathrm{ml} \mathrm{SDF-1} \mathrm{was} \mathrm{selected} \mathrm{for} \mathrm{subsequent}$ experiments (Fig. 2A). Moreover, there was no statistical difference in the OD values between the $10 \mathrm{ng} / \mathrm{ml} \mathrm{SDF}-1$ group and the control group.

To investigate the underlying signaling pathway associated with SDF-1-induced EPC proliferation, the MTS assay was performed. SDF-1 group could significantly increase the proliferation of EPCs compared with the control group. SDF-1-induced proliferation was significantly inhibited by pretreatment with AMD3100, LY294002 or PD98059, 

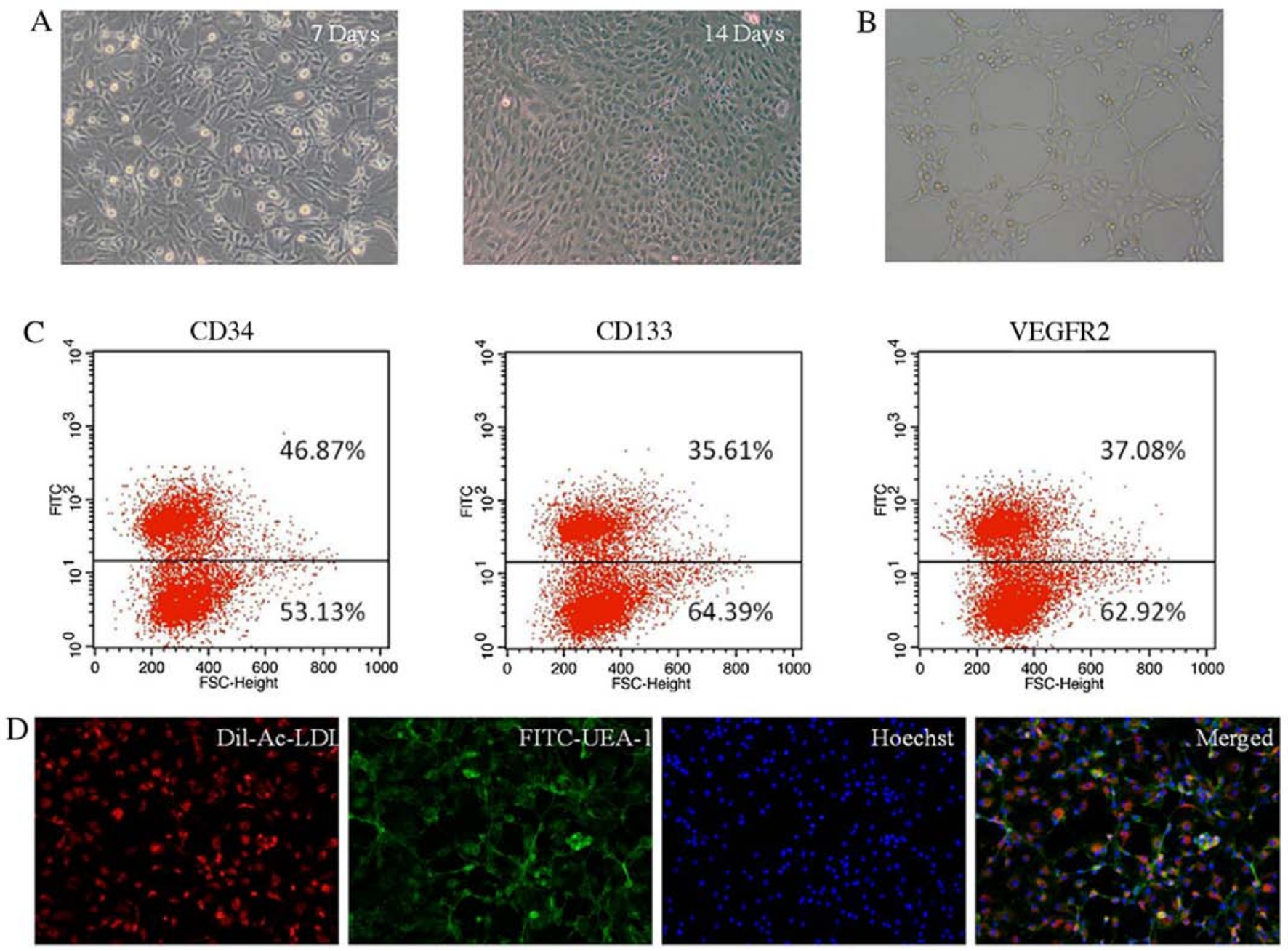

Figure 1. Identification of EPCs. (A) Typical cell morphology following 7 and 14 days of culture (magnification, x200). (B) Tube formation ability on Matrigel ${ }^{\circledR}$ matrix (magnification, x200). (C) Adherent cells were analyzed for CD34, CD133 and VEGFR2 expression by flow cytometry. (D) Following culture for 7 days, cells were able to take up DiI-ac-LDL and bind with FITC-UEA-1. Cell nuclei were stained blue with Hoechst (magnification, x200). EPC, endothelial progenitor cell; VEGFR2, vascular endothelial growth factor receptor 2; DiI-ac-LDL, dil-labelled acetylated low-density lipoprotein; UEA, Ulex europaeus agglutinin.

compared with the SDF-1-treated group (Fig. 2B). Collectively, the results suggested that the Akt and ERK signal transduction pathways were associated with SDF-1-induced EPC proliferation.

LY294002 reverses SDF-1-induced EPC migration and tube formation. To investigate the effect of SDF-1 on EPC migration, the migratory ability of EPCs was evaluated using the Transwell assay. The number of migratory cells in the SDF-1-treatment group was significantly increased compared with the negative control group. Furthermore, AMD3100 and LY294002 significantly reduced SDF-1-induced EPC migration compared with the SDF-1 group. There was no significant difference in the migration of EPCs between the SDF-1 group and PD98059 group (Fig. 3). Therefore, the results demonstrated that the Akt signaling pathway served an important role during SDF-1-induced EPC migration.

The tube-like formation assay was performed to examine the effect of SDF-1 on tube-like structure formation. Compared with the control group, the number of tube-like structures in the SDF-1 group was significantly increased (Fig. 4). Pretreatment with AMD3100 and LY294002 significantly attenuated SDF-1-induced EPC tube-like tube formation. No significant difference in tube formation of EPCs was found between the SDF-1 group and PD98059 group. Thus, the results suggested that the Akt signaling pathway, but not ERK signaling, was associated with SDF-1-induced EPC tube-like formation.

Various inhibitors attenuate SDF-1-stimulated Akt and ERK phosphorylation. To investigate whether the PI3K/Akt signaling pathway was involved in EPC biological functions, the phosphorylation/activation levels of Akt were examined by western blotting following stimulation with SDF-1. SDF-1 treatment significantly upregulated the protein expression of p-Akt, which was reversed by AMD3100 or LY294002 (Fig. 5A and B), indicating activation of the Akt signaling pathway. Based on the finding that SDF-1-induced EPC proliferation, migration and tube formation were attenuated by LY294002, it was speculated that the Akt signaling pathway was associated with SDF-1-mediated EPC proliferation, migration and tube formation.

SDF-1 also upregulated the protein expression of p-ERK in EPCs, and pretreatment with AMD3100 or PD98059 significantly 

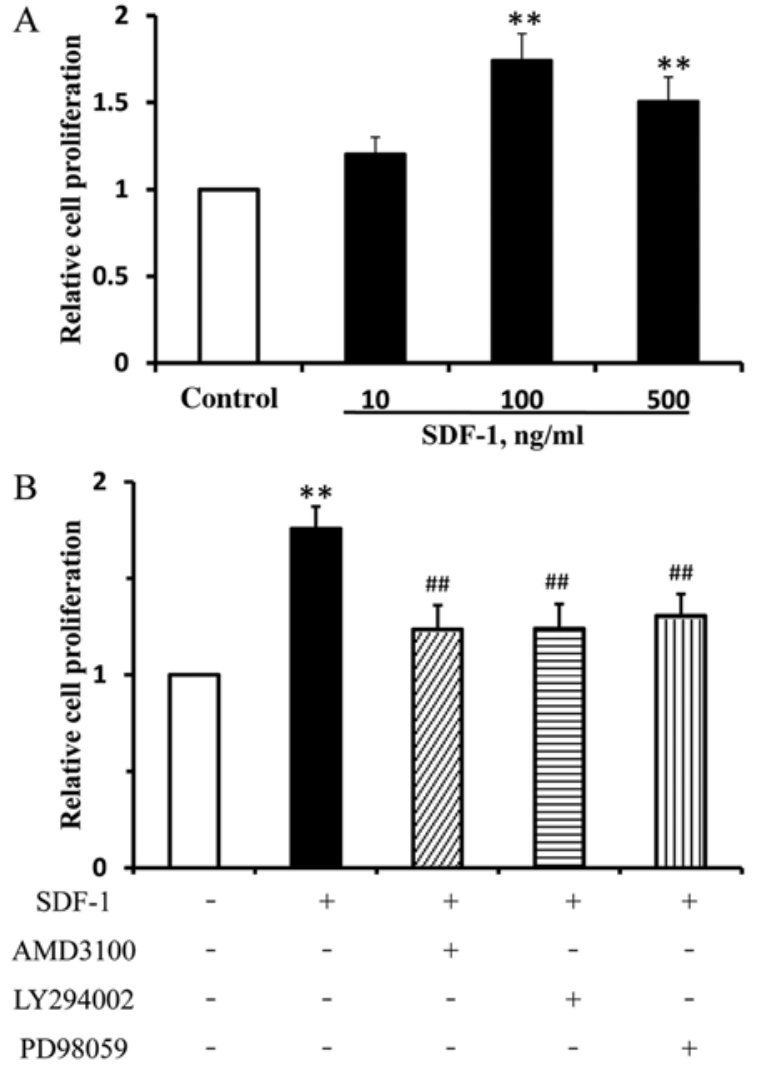

Figure 2. EPC proliferation assessed by the MTS assay. (A) EPCs were treated with SDF-1 at different doses $(10,100$ and $500 \mathrm{ng} / \mathrm{ml})$ and cell proliferation was assessed using the MTS assay. (B) EPCs were pretreated with AMD3100 $(60 \mu \mathrm{M}), \mathrm{LY} 294002(20 \mu \mathrm{M})$ or PD98059 $(20 \mu \mathrm{M})$ and incubated with SDF-1 $(100 \mathrm{ng} / \mathrm{ml})$. Cell proliferation was measured using the MTS assay. ${ }^{* *} \mathrm{P}<0.01$ vs. control; ${ }^{\# \#} \mathrm{P}<0.01$ vs. SDF-1. EPC, endothelial progenitor cells; SDF-1, stromal cell-derived factor-1.

reduced SDF-1-induced increases in ERK phosphorylation (Fig. 5C and D), thus suggesting that the ERK signaling pathway was required for SDF-1-induced EPC proliferation.

\section{Discussion}

In the present study, the potential effects of SDF-1 on EPCs and the underlying mechanisms were investigated. The results suggested that SDF-1 significantly stimulated EPC functional characteristics, such as cell proliferation, migration and tube formation. SDF-1-induced EPC proliferation was inhibited by the CXCR4 antagonist (AMD3100), the PI3K inhibitor (LY294002) and the MEK inhibitor (PD98059). However, SDF-1-induced migration and tube formation were only attenuated by AMD3100 and LY294002. To further investigate the underlying molecular mechanisms, western blotting was performed. The results indicated thatSDF-1 treatment stimulated Akt and ERK phosphorylation; however, pretreatment with AMD3100, LY294002 and PD98059 blocked SDF-1-induced phosphorylation. Moreover, SDF-1-induced EPC proliferation was accompanied by Akt and ERK phosphorylation. Thus, the Akt signaling pathway via CXCR4 may serve critical roles during SDF-1-induced EPC proliferation, migration and tube formation. In addition, ERK activation was associated with EPC proliferation, but it was not required for SDF-1-induced EPC migration and tube formation.

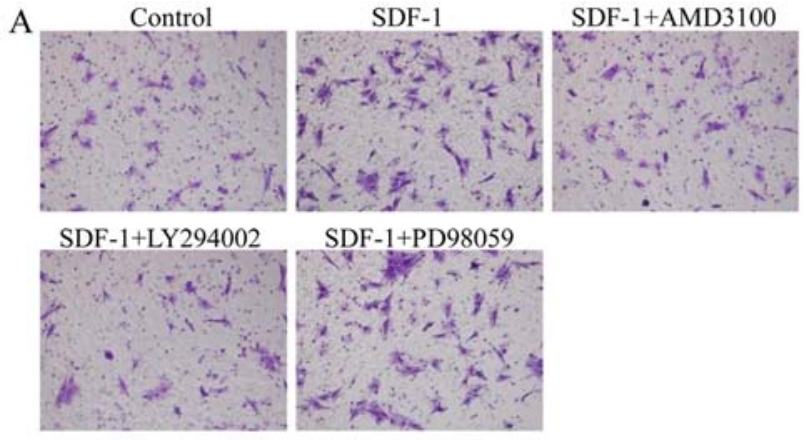

B

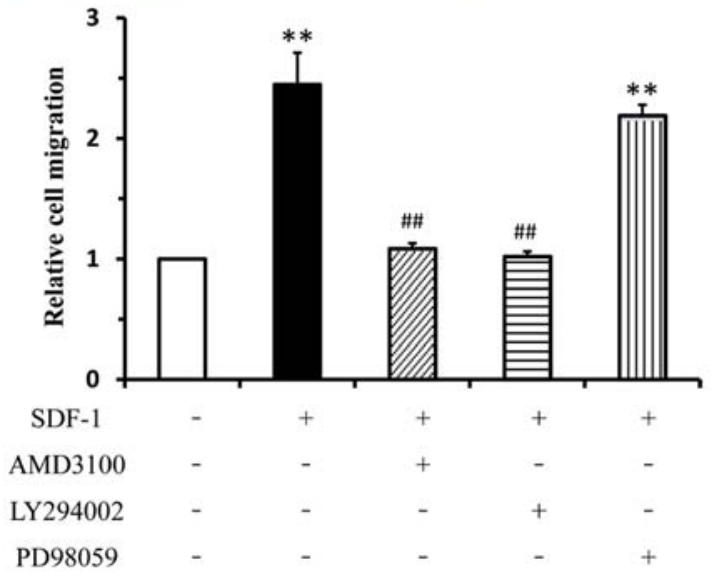

Figure 3. EPC migration assessed using the Transwell migration assay. (A) Representative images of migratory cells (magnification, x100). (B) Relative cell migration. ${ }^{* *} \mathrm{P}<0.01$ vs. control; ${ }^{\#} \mathrm{P}<0.01$ vs. SDF-1. EPC, endothelial progenitor cell; SDF-1, stromal cell-derived factor-1.

Since Asahara et al (1) first described human circulating $\mathrm{CD}^{+} 4^{+}$cells as EPCs, other studies have reported that EPCs migrate to sites of injured blood vessels, differentiate into mature endothelial cells and participate in re-endothelialization (38-40). It has also been revealed that EPCs have important roles during neovascularization (41), vascular repair (42) and various diseases, such as cerebrovascular disease (12), cardiovascular disease (13), chronic kidney disease (14) and cancer (15).

Numerous cytokines are released in injured or ischemic tissue, of which SDF-1 and VEGF are the most important (43). VEGF is the most specific and potent angiogenic factor (44). A previous study showed that SDF-1 can mobilize and recruit EPCs to participate in angiogenesis, and VEGF is an important factor involved in this process (35). A recent study has also reported that VEGF and SDF-1 have significant synergistic effects on the angiogenic properties of EPCs (45). Collectively, it was speculated that VEGF and SDF-1 exert significant synergistic effects on the angiogenesis of EPCs.

SDF-1 is primarily secreted by stromal fibroblasts and vascular endothelial cells, and is constitutively expressed in multiple tissues, including the liver, lung, brain, kidney, heart, colon, lymph nodes, skin and bone marrow (18). SDF-1 binds to the transmembrane $\mathrm{G}$ protein-coupled receptors CXCR4 and CXCR7 (46). CXCR4 was previously considered to be the only SDF-1 receptor until the identification of CXCR7 in T lymphocytes $(47,48)$. Compared with CXCR4, the affinity of CXCR7 to SDF-1 is higher (47). Furthermore, SDF-1 binding to $\mathrm{CXCR} 4$ leads to the activation of $\mathrm{G}$ protein 
signaling kinases, including PI3K and MAPK signaling pathways, as well as the NF- $\kappa B$ signaling pathway (18). However, binding of SDF-1 to CXCR7 signals via the $\beta$-arrestin pathway, which is not via a $G$ protein-mediated signaling pathway (49). CXCR7 can form heterodimers with CXCR4 to form a structural trigger of the downstream signaling pathway (50). Although the exact function of CXCR7 is not completely understood, previous studies have reported that CXCR7 is closely related to cell survival (51), proliferation (52) and adhesion (53), as well as the formation of the SDF-1 concentration gradient (54).

SDF-1 binds to the G-coupled protein receptor CXCR4 to initiate downstream signaling molecules and induce diverse biological processes, including cell proliferation, migration, survival and senescence (55). Previous studies have revealed that CXCR4 expression is associated with EPC homing, subsequent endothelial regeneration and the angiogenic response $(56,57)$. The present results suggested that SDF-1 treatment increased EPC migration, which was consistent with the results of previous studies $(23,35)$. In addition, SDF-1-induced proliferation and angiogenesis were significantly blocked by the CXCR4 antagonist AMD3100. In line with previous studies $(35,56,57)$, the present study identified a potential role for CXCR4 for the integration of EPCs into the vascular bed, and further indicated that SDF-1 modulated EPC proliferation, migration and angiogenesis. However, the underlying downstream pathways of SDF-1 that are associated with EPC viability, migration and angiogenesis require further investigation.

Previous studies have revealed that the SDF-1/CXCR4 axis is associated with cell proliferation and migration via activation of several signal transduction pathways, including the PI3K/Akt signaling pathway (29,33). Akt serves an important role during cell proliferation, differentiation and survival, and regulates a number of genes that are downstream targets of PI3K (58). The PI3K/Akt signaling pathway is also required for the biological features of EPCs that are induced by diverse pathophysiological and interventional interventions (59). A recent study revealed that SDF-1 increased EPC proliferation, colony formation, migration and angiogenesis (60); however, the molecular mechanisms underlying the biological activities of SDF-1 on EPCs are not fully understood. Consistent with a previous study (60), the present results also demonstrated that SDF-1 promoted the functional activities of EPCs. Furthermore, inhibition of Akt blocked SDF-1-induced EPC biological functions, such as proliferation, migratory and angiogenesis. To further investigate the involvement of the Akt signal transduction pathway in the process, the effect of SDF-1 on the protein expression levels of Akt and p-Akt in EPCs were assessed by western blotting. The results demonstrated that SDF-1-treated EPCs had increased Akt phosphorylation, and pretreatment with the PI3K inhibitor LY294002 significantly decreased SDF-1-induced p-Akt expression. It was also found that the Akt signaling pathway was required for SDF-1-induced EPC biological functions. Moreover, CXCR4 inhibition by ADM3100 significantly attenuated SDF-1-induced EPC biological functions and p-Akt activity. Therefore, the CXCR4-mediated PI3K/Akt signaling pathway may serve a key role during SDF-1-induced EPC viability, migratory and angiogenesis.
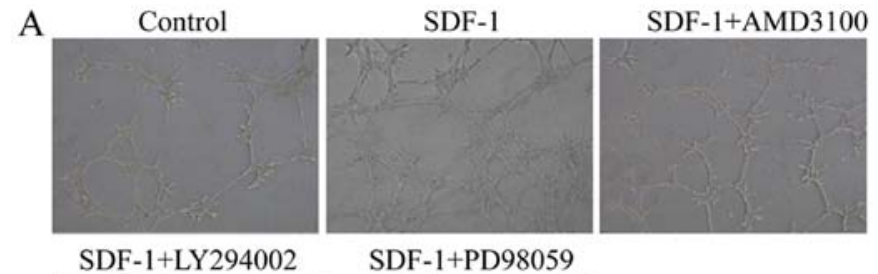

SDF-1+PD98059
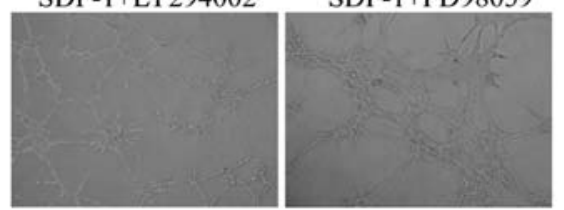

B

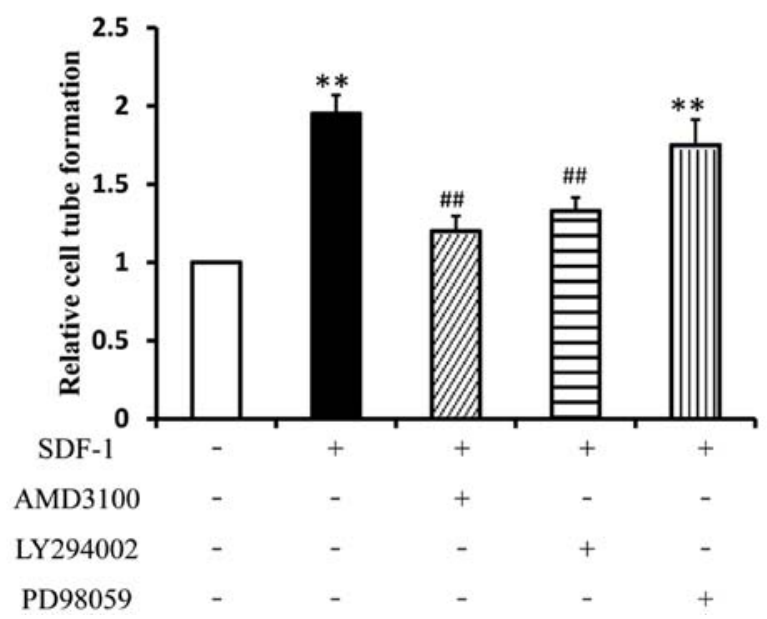

Figure 4. EPC tube formation on Matrigel ${ }^{\circledR}$. (A) Representative images of Matrige ${ }^{\circledR}$ tube formation (magnification, x100). (B) Quantification of the total branching length. ${ }^{* *} \mathrm{P}<0.01$ vs. control; ${ }^{\#} \mathrm{P}<0.01$ vs. SDF-1. EPC, endothelial progenitor cell; SDF-1, stromal cell-derived factor-1.

The MAPK/ERK signaling pathway is a chain of proteins in the cell that can transduce extracellular information into intracellular responses, and are associated with the regulation of a variety of growth and differentiation signaling pathways via several phosphorylation cascades (58). Previous studies have reported that low-dose radiation and basic fibroblast growth factor can promote EPC proliferation and migration via activation of the ERK signaling pathway $(61,62)$. In addition, the ERK signaling pathway is associated with the regulation of EPC angiogenesis (63). Thus, the aforementioned studies revealed that the ERK signaling pathway may serve an important role during EPC proliferation, migration and angiogenesis. SDF-1/CXCR4 signal transduction stimulates ERK activation during lung cancer (28), sacral chondrosarcoma (29), glioblastoma (30) and in ovarian cancer (31) cell lines. To the best of our knowledge, the association between SDF-1-induced EPC functions and the ERK signaling pathway has not been previously reported. Therefore, the present study investigated whether the ERK signaling pathway was regulated in EPCs in response to SDF-1. The results indicated that SDF-1-induced proliferation was accompanied by ERK phosphorylation. Moreover, the MEK inhibitor PD98059 decreased SDF-1-induced p-ERK protein expression and EPC proliferation, but had no effect on SDF-1-induced migration and tube formation. Therefore, it was speculated that the ERK signaling pathway was associated with SDF-1-induced EPC proliferation, but not EPC migration and tube formation. 
A

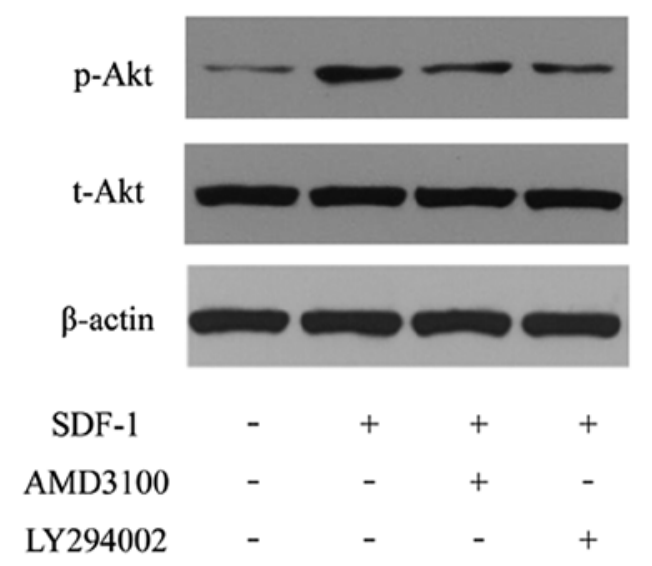

C

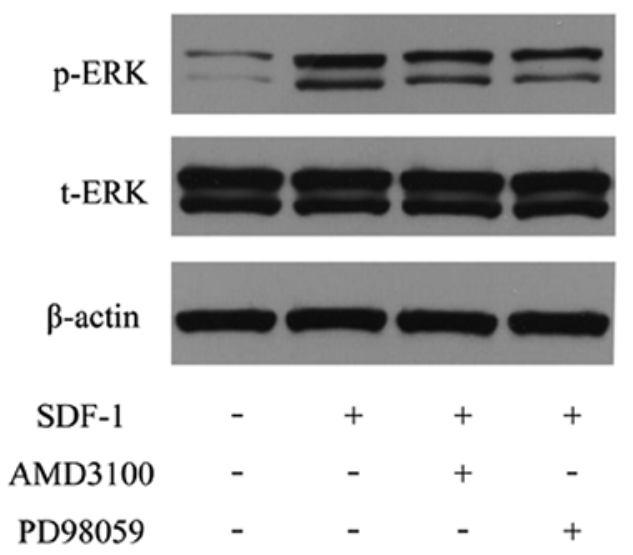

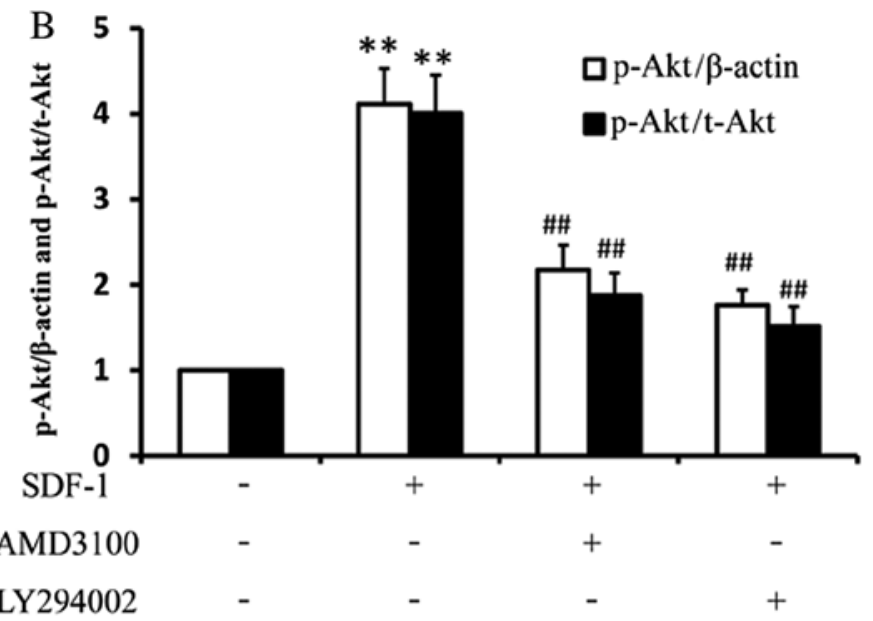
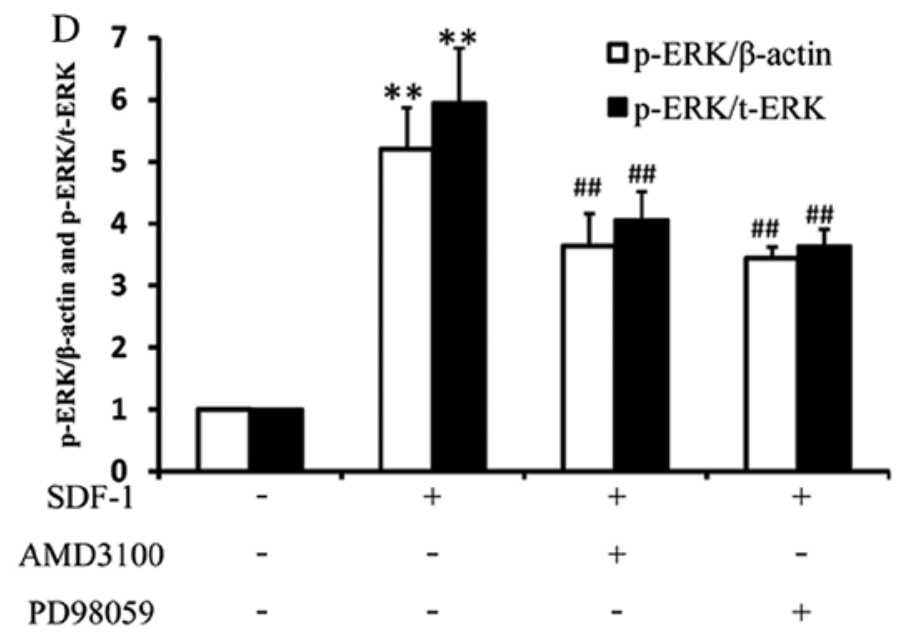

Figure 5. Signaling pathway inhibition reverses SDF-1-induced Akt and ERK phosphorylation. (A) t-Akt and p-Akt protein expression levels were determined by western blotting and (B) quantified. (C) t-ERK and p-ERK protein expression levels were determined by western blotting and (D) quantified. ${ }^{* *} \mathrm{P}<0.01$ vs. control; ${ }^{\#} \mathrm{P}<0.01$ vs. SDF-1. SDF-1, stromal cell-derived factor-1; $\mathrm{p}$, phosphorylated; $\mathrm{t}-$, total.

The present study had a number of limitations that require consideration. For example, the SDF-1/CXCR4 axis activates several signaling pathways (18), including the PI3K/Akt, MEK/ERK, NF- $\kappa$ B, Ras-activated, Janus kinase/STAT and $G$ protein-coupled receptor kinase- $\beta$-arrestin signaling pathways. However, the present study primarily focused on the PI3K/Akt and MAPK/ERK signaling pathways. Thus, whether SDF-1 promotes EPC proliferation, migration and tube formation via other signaling pathways should be examined in future studies. Furthermore, the other SDF-1 receptor, $\mathrm{CXCR} 7$, requires further investigation. The roles of the SDF-1/CXCR4 and SDF-1/CXCR7 signaling pathways, as well as their crosstalk in EPC biological functions should also be investigated in future studies.

In conclusion, to the best of our knowledge, the present study was the first to demonstrate that SDF-1 stimulated EPC proliferation via activation of the CXCR4-dependent Akt and ERK signaling pathways. Moreover, the Akt signaling pathway also contributed to SDF-1-induced EPC migration and tube formation. The results of the present study may further the understanding of the molecular mechanisms underlying SDF-1-mediated EPC functions, as well as provide an insight into potential therapeutic targets for cerebrovascular disease, cardiovascular disease, chronic kidney disease and cancer.

\section{Acknowledgements}

Not applicable.

\section{Funding}

The present study was supported by the China Postdoctoral Science Foundation (grant no. 2017M623431).

\section{Availability of data and materials}

All data generated or analyzed during this study are included in this published article.

\section{Authors' contributions}

YC, LM and ZR conceived and designed the study. BD and $\mathrm{ZZ}$ interpreted and analyzed the data. YC drafted the manuscript. LM and ZR critically revised the manuscript. YC, GW and JY performed the cell culture and experimental 
procedures. All authors read and approved the final manuscript.

\section{Ethics approval and consent to participate}

Experimental protocols involving the use of animals were approved by the Animal Research Committee of the General Hospital of Central Theater Command (Wuhan, China).

\section{Patient consent for publication}

Not applicable.

\section{Competing interests}

The authors declare that they have no competing interests.

\section{References}

1. Asahara T, Murohara T, Sullivan A, Silver M, van der Zee R, Li T, Witzenbichler B, Schatteman G and Isner JM: Isolation of putative progenitor endothelial cells for angiogenesis. Science 275 964-966, 1997.

2. Zhang M, Rehman J and Malik AB: Endothelial progenitor cells and vascular repair. Curr Opin Hematol 21: 224, 2014.

3. Li Y, Wang Z, Mao M, Zhao M, Xiao X, Sun W, Guo J, Liu C, Yang D, Qiao J, et al: Velvet antler mobilizes endothelial progenitor cells to promote angiogenesis and repair vascular endothelial injury in rats following myocardial infarction. Front Physiol 9: 1940, 2018

4. Hu Q, Ke X, Zhang T, Chen Y, Huang Q, Deng B, Xie S, Wang J and Nie R: Hydrogen sulfide improves vascular repair by promoting endothelial nitric oxide synthase-dependent mobilization of endothelial progenitor cells. J Hypertens 37: 972-984, 2019.

5. Hu Z, Wang H, Fan G, Zhang H, Wang X, Mao J, Zhao Y, An Y, Huang Y, Li C, et al: Danhong injection mobilizes endothelial progenitor cells to repair vascular endothelium injury via upregulating the expression of Akt, eNOS and MMP-9. Phytomedicine 61: 152850, 2019.

6. Wei H, Mao Q, Liu L, Xu Y, Chen J, Jiang R, Yin L, Fan Y, Chopp M, Dong J and Zhang J: Changes and function of circulating endothelial progenitor cells in patients with cerebral aneurysm. J Neurosci Res 89: 1822-1828, 2011.

7. Xu Y, Tian Y, Wei HJ, Chen J, Dong JF, Zacharek A and Zhang JN: Erythropoietin increases circulating endothelial progenitor cells and reduces the formation and progression of cerebral aneurysm in rats. Neuroscience 181: 292-299, 2011.

8. Urbich C and Dimmeler S: Endothelial progenitor cells: Functional characterization. Trends Cardiovasc Med 14: 318-322, 2004.

9. Moccia F, Zuccolo E, Poletto V, Cinelli M, Bonetti E, Guerra G and Rosti V: Endothelial progenitor cells support tumour growth and metastatisation: Implications for the resistance to anti-angiogenic therapy. Tumor Biol 36: 6603-6614, 2015.

10. Flamini V, Jiang WG, Lane J and Cui YX: Significance and therapeutic implications of endothelial progenitor cells in angiogenic-mediated tumour metastasis. Crit Rev Oncol Hematol 100: $177-189,2016$.

11. Zhao X, Liu HQ, Li J and Liu XL: Endothelial progenitor cells promote tumor growth and progression by enhancing new vessel formation. Oncol Lett 12: 793-799, 2016.

12. Jung KH and Roh JK: Circulating endothelial progenitor cells in cerebrovascular disease. J Clin Neurol 4: 139-147, 2008.

13. Sheng ZQ, Li YF, Zheng KL, Lu HH, Xie J, Wu H and Xu B The relationship between number and function of EPCs and concentration of VEGF165 and SDF-1 in coronary artery spasm. Eur Rev Med Pharmacol Sci 22: 2767-2777, 2018.

14. Coppolino G, Cernaro V, Placida G, Leonardi G, Basile G and Bolignano D: Endothelial progenitor cells at the interface of chronic kidney disease: From biology to therapeutic advancement. Curr Med Chem 25: 4545-4551, 2018.

15. Ammendola M, Leporini C, Luposella M, Sacco R, Sammarco G, Russo E, Patruno R, De Sarro G and Ranieri G: Targeting endothelial progenitor cells in cancer as a novel biomarker and anti-angiogenic therapy. Curr Stem Cell Res Ther 10: 181-187, 2015.
16. Nagasawa T, Kikutani $\mathrm{H}$ and Kishimoto T: Molecular cloning and structure of a pre-B-cell growth-stimulating factor. Proc Natl Acad Sci USA 91: 2305-2309, 1994.

17. Ratajczak M, Zuba-Surma E, Kucia M, Reca R, Wojakowski W and Ratajczak J: The pleiotropic effects of the SDF-1-CXCR4 axis in organogenesis, regeneration and tumorigenesis. Leukemia 20: 1915-1924, 2006.

18. Teicher BA and Fricker SP: CXCL12 (SDF-1)/CXCR4 pathway in cancer. Clin Cancer Res 16: 2927-2931, 2010.

19. Möhle R, Bautz F, Rafii S, Moore MA, Brugger W and Kanz L: The chemokine receptor CXCR-4 is expressed on CD34+ hematopoietic progenitors and leukemic cells and mediates transendothelial migration induced by stromal cell-derived factor-1. Blood 91: 4523-4530, 1998

20. Walter DH, Haendeler J, Reinhold J, Rochwalsky U, Seeger F, Honold J, Hoffmann J, Urbich C, Lehmann R, Arenzana-Seisdesdos F, et al: Impaired CXCR4 signaling contributes to the reduced neovascularization capacity of endothelial progenitor cells from patients with coronary artery disease. Circ Res 97: 1142-1151, 2005.

21. Hattori K, Heissig B, Tashiro K, Honjo T, Tateno M, Shieh JH, Hackett NR, Quitoriano MS, Crystal RG, Rafii S and Moore MA: Plasma elevation of stromal cell-derived factor-1 induces mobilization of mature and immature hematopoietic progenitor and stem cells. Blood 97: 3354-3360, 2001.

22. Hoenig MR, Bianchi C and Sellke FW: Hypoxia inducible factor-1 $\alpha$, endothelial progenitor cells, monocytes, cardiovascular risk, wound healing, cobalt and hydralazine: A unifying hypothesis. Curr Drug Targets 9: 422-435, 2008.

23. Yamaguchi JI, Kusano KF, Masuo O, Kawamoto A, Silver M, Murasawa S, Bosch-Marce M, Masuda H, Losordo DW, Isner JM and Asahara T: Stromal cell-derived factor-1 effects on ex vivo expanded endothelial progenitor cell recruitment for ischemic neovascularization. Circulation 107: 1322-1328, 2003.

24. Kawakami Y, Ii M, Matsumoto T, Kuroda R, Kuroda T, Kwon SM, Kawamoto A, Akimaru H, Mifune Y, Shoji T, et al: SDF-1/CXCR4 axis in Tie2-lineage cells including endothelial progenitor cells contributes to bone fracture healing. J Bone Miner Res 30: 95-105, 2015.

25. Carmeliet P: Mechanisms of angiogenesis and arteriogenesis. Nat Med 6: 389-395, 2000.

26. Ganju RK, Brubaker SA, Meyer J, Dutt P, Yang Y, Qin S, Newman W and Groopman JE: The $\alpha$-chemokine, stromal cell-derived factor-1alpha, binds to the transmembrane G-protein-coupled CXCR-4 receptor and activates multiple signal transduction pathways. J Biol Chem 273: 23169-23175, 1998.

27. Libura J, Drukala J, Majka M, Tomescu O, Navenot JM, Kucia M, Marquez L, Peiper SC, Barr FG, Janowska-Wieczorek A and Ratajczak MZ: CXCR4-SDF-1 signaling is active in rhabdomyosarcoma cells and regulates locomotion, chemotaxis, and adhesion. Blood 100: 2597-2606, 2002.

28. Zeng Y, Wang X, Yin B, Xia G, Shen Z, Gu W and Wu M: Role of the stromal cell derived factor-1/CXC chemokine receptor 4 axis in the invasion and metastasis of lung cancer and mechanism. J Thorac Dis 9: 4947-4959, 2017.

29. Yang P, Wang G, Huo H, Li Q, Zhao Y and Liu Y: SDF-1/CXCR4 signaling up-regulates survivin to regulate human sacral chondrosarcoma cell cycle and epithelial-mesenchymal transition via ERK and PI3K/AKT pathway. Med Oncol 32: 377 , 2015.

30. Liao A, Shi R, Jiang Y, Tian S, Li P, Song F, Qu Y, Li J, Yun H and Yang X: SDF-1/CXCR4 axis regulates cell cycle progression and epithelial-mesenchymal Transition via up-regulation of survivin in glioblastoma. Mol Neurobiol 53: 210-215, 2016.

31. Porcile C, Bajetto A, Barbieri F, Barbero S, Bonavia R, Biglieri M, Pirani P, Florio T and Schettini G: Stromal cell-derived factor-1alpha (SDF-1alpha/CXCL12) stimulates ovarian cancer cell growth through the EGF receptor transactivation. Exp Cell Res 308: 241-253, 2005.

32. Lu Y, Hu B, Guan GF, Chen J, Wang CQ, Ma Q, Wen YH, Qiu XC, Zhang XP and Zhou Y: SDF-1/CXCR4 promotes F5M2 osteosarcoma cell migration by activating the Wnt/ $\beta$-catenin signaling pathway. Med Oncol 32: 194, 2015.

33. Peng SB, Peek V, Zhai Y, Paul DC, Lou Q, Xia X, Eessalu T, Kohn W and Tang S: Akt activation, but not extracellular signal-regulated kinase activation, is required for SDF-1 $\alpha / C X C R 4$-mediated migration of epitheloid carcinoma cells. Mol Cancer Res 3: 227-236, 2005. 
34. Segal MS, Shah R, Afzal A, Perrault CM, Chang K, Schuler A, Beem E, Shaw LC, Li Calzi S, Harrison JK, et al: Nitric oxide cytoskeletal-induced alterations reverse the endothelial progenitor cell migratory defect associated with diabetes. Diabetes 55 : 102-109, 2006.

35. Zheng H, Fu G, Dai T and Huang H: Migration of endothelial progenitor cells mediated by stromal cell-derived factor-1 $\alpha /$ CXCR4 via PI3K/Akt/eNOS signal transduction pathway. J Cardiovasc Pharmacol 50: 274-280, 2007.

36. National Research Council (US) Committee for the Update of the Guide for the Care and Use of Laboratory Animals: In: Guide for the Care and Use of Laboratory Animals National Academies Press (US) Copyright ${ }^{\odot}$ 2011, National Academy of Sciences, Washington (DC), 2011.

37. Kruger NJ: The Bradford method for protein quantitation. Methods Mol Biol 32: 9-15, 1994.

38. Balaji S, King A, Crombleholme TM and Keswani SG: The role of endothelial progenitor cells in postnatal vasculogenesis: Implications for therapeutic neovascularization and wound healing. Adv Wound Care (New Rochelle) 2: 283-295, 2013.

39. Lu C, Zhang J, Zhang D, Uzan G and Li M: EPCs in vascular repair: How can we clear the hurdles between bench and bedside? Front Biosci (Landmark Ed) 19: 34, 2014

40. Li L, Liu H, Xu C, Deng M, Song M, Yu X, Xu S and Zhao X: VEGF promotes endothelial progenitor cell differentiation and vascular repair through connexin 43. Stem Cell Res Ther 8: 237, 2017.

41. Li DW, Liu ZQ, Wei J, Liu Y and Hu LS: Contribution of endothelial progenitor cells to neovascularization. Int J Mol Med 30: 1000-1006, 2012.

42. Dimmeler S and Zeiher AM: Vascular repair by circulating endothelial progenitor cells: The missing link in atherosclerosis? J Mol Med (Berl) 82: 671-677, 2004.

43. Liu SQ, Tefft BJ, Zhang D, Roberts D, Schuster DJ and Wu A: Cardioprotective mechanisms activated in response to myocardial ischemia. Mol Cell Biomech 8: 319-338, 2011.

44. Ahluwalia A, Jones MK, Matysiakbudnik T and Tarnawski AS VEGF and colon cancer growth beyond angiogenesis: Does VEGF directly mediate colon cancer growth via a non-angiogenic mechanism? Curr Pharm Des 20: 1041-1044, 2014.

45. Odent Grigorescu G, Rosca AM, Preda MB, Tutuianu R, Simionescu M and Burlacu A: Synergic effects of VEGF-A and SDF-1 on the angiogenic properties of endothelial progenitor cells. J Tissue Eng Regen Med 11: 3241-3252, 2017.

46. Lipfert J, Odemis V, Wagner D, Boltze J and Engele J: CXCR4 and CXCR7 form a functional receptor unit for SDF-1/CXCL12 in primary rodent microglia. Neuropathol Appl Neurobiol 39: 667-680, 2013

47. Balabanian K, Lagane B, Infantino S, Chow KY, Harriague J, Moepps B, Arenzana-Seisdedos F, Thelen M and Bachelerie F: The chemokine SDF-1/CXCL12 binds to and signals through the orphan receptor RDC1 in T lymphocytes. J Biol Chem 280: 35760-35766, 2005

48. Burns JM, Summers BC, Wang Y, Melikian A, Berahovich R, Miao Z, Penfold ME, Sunshine MJ, Littman DR, Kuo CJ, et al: A novel chemokine receptor for SDF-1 and I-TAC involved in cell survival, cell adhesion, and tumor development. J Exp Med 203: 2201-2213, 2006

49. Rajagopal S, Kim J, Ahn S, Craig S, Lam CM, Gerard NP Gerard $C$ and Lefkowitz RJ: $\beta$-arrestin-but not $G$ protein-mediated signaling by the 'decoy' receptor CXCR7. Proc Natl Acad Sci USA 107: 628-632, 2010.

50. Puchert M and Engele J: The peculiarities of the SDF-1/CXCL12 system: In some cells, CXCR4 and CXCR7 sing solos, in others, they sing duets. Cell Tissue Res 355: 239-253, 2014.
51. Badillo AT, Chung S, Zhang L, Zoltick P and Liechty KW: Lentiviral gene transfer of SDF-1 $\alpha$ to wounds improves diabetic wound healing. J Surg Res 143: 35-42, 2007.

52. Yoshida D, Nomura $R$ and Teramoto A: Signalling pathway mediated by CXCR7, an alternative chemokine receptor for stromal-cell derived factor-1 $\alpha$, in AtT20 mouse adrenocorticotrophic hormone-secreting pituitary adenoma cells. J Neuroendocrinol 21: 481-488, 2009.

53. Hartmann TN, Grabovsky V, Pasvolsky R, Shulman Z, Buss EC, Spiegel A, Nagler A, Lapidot T, Thelen M and Alon R: A crosstalk between intracellular CXCR7 and CXCR4 involved in rapid CXCL12-triggered integrin activation but not in chemokinetriggered motility of human T lymphocytes and CD34+ cells. J Leukoc Biol 84: 1130-1140, 2008.

54. Boldajipour B, Mahabaleshwar H, Kardash E, Reichman-Fried M, Blaser H, Minina S, Wilson D, Xu Q and Raz E: Control of chemokine-guided cell migration by ligand sequestration. Cell 132: 463-473, 2008.

55. Pozzobon T, Goldoni G, Viola A and Molon B: CXCR4 signaling in health and disease. Immunol Lett 177: 6-15, 2016.

56. Chen L, Wu F, Xia WH, Zhang YY, Xu SY, Cheng F, Liu X, Zhang XY, Wang SM and Tao J: CXCR4 gene transfer contributes to in vivo reendothelialization capacity of endothelial progenitor cells. Cardiovasc Res 88: 462-470, 2010.

57. Wu Q, Shao H, Darwin Eton D, Li J, Li J, Yang B, Webster KA and Yu H: Extracellular calcium increases CXCR4 expression on bone marrow-derived cells and enhances pro-angiogenesis therapy. J Cell Mol Med 13: 3764-3773, 2009.

58. Rai SN, Dilnashin H, Birla H, Singh SS, Zahra W, Rathore AS, Singh BK and Singh SP: The role of PI3K/Akt and ERK in neurodegenerative disorders. Neurotox Res 35: 775-795, 2019.

59. Everaert BR, Van Craenenbroeck EM, Hoymans VY, Haine SE, Van Nassauw L, Conraads VM, Timmermans JP and Vrints CJ: Current perspective of pathophysiological and interventional effects on endothelial progenitor cell biology: Focus on PI3K/AKT/eNOS pathway. Int J Cardiol 144: 350-366, 2010.

60. Keshavarz S, Nassiri SM, Siavashi V and Alimi NS: Regulation of plasticity and biological features of endothelial progenitor cells by MSC-derived SDF-1. Biochim Biophys Acta Mol Cell Res 1866: 296-304, 2019.

61. Guo S, Yu L, Cheng Y, Li C, Zhang J, An J, Wang H, Yan B, Zhan T, Cao Y, et al: PDGFR $\beta$ triggered by bFGF promotes the proliferation and migration of endothelial progenitor cells via p-ERK signalling. Cell Biol Int 36: 945-950, 2012.

62. Wang P, Zhang H, Li Z, Liu X, Jin Y, Lei M, Jiao Z, Bi Y and Guo W: Low-dose radiation promotes the proliferation and migration of AGE-treated endothelial progenitor cells derived from bone marrow via activating SDF-1/CXCR4/ERK signaling pathway. Radiat Res 191: 518-526, 2019.

63. Rosell A, Arai K, Lok J, He T, Guo S, Navarro M, Montaner J, Katusic ZS and Lo EH: Interleukin-1 $\beta$ augments angiogenic responses of murine endothelial progenitor cells in vitro. J Cereb Blood Flow Metab 29: 933-943, 2009.

(i)(9) This work is licensed under a Creative Commons Attribution-NonCommercial-NoDerivatives 4.0 International (CC BY-NC-ND 4.0) License. 